\title{
Damage scenario of the earthquake on 23 July 1930 in Melfi: the contribution of technical documentation
}

\author{
Fabrizio Terenzio Gizzi and Nicola Masini \\ CNR - Istituto per i Beni Archeologici e Monumentali (IBAM), Sezione di Potenza, Lagopesole (PZ), Italy
}

\begin{abstract}
As regards the 1930 Irpinia earthquake a detailed research both on the institutional response to the seismic event in Vulture area and reconstruction of the damage scenario for the town of Melfi has been performed. This study was carried out by an analysis of coeval dossiers drawn up by the Special Office of Civil Engineers, which was set up after the earthquake. The research brought to light the typologies and the modalities of the institutional actions taken during the post-seismic period. In general, these territorial interventions had a notable effect on urban systems, especially those involving both the partial shifting of urban areas and the construction of earthquake-proof buildings. The research also identified the damage pattern in Melfi by a deeper study on about 2400 archive files. A preliminary analysis of the damage pattern indicates probable seismic amplification phenomena due to the lithological and geomorphological features of the site. Moreover, the analysis of time-dependent activities of reconstruction has shown that almost all the buildings of the town (90\%) were repaired or reconstructed within five years after the seismic disaster.
\end{abstract}

Key words historical seismology - damage scenario - Melfi - 1930 Irpinia earthquake - seismic amplification

\section{Introduction}

Three years ago, the authors started a research project on historical earthquake damage relative to the towns of an important area of Southern Italy, the Vulture district, located in the north-eastern portion of the Basilicata Region. In this zone, Melfi represents the most significant case study on the relationship between urban and seismic history. Indeed, consulting the $\mathrm{Ca}$ talogue of Strong Italian Earthquakes (Boschi

Mailing address: Dr. Fabrizio Terenzio Gizzi, CNR Istituto per i Beni Archeologici e Monumentali (IBAM), Sezione di Potenza, Via Federico II, 85020 Lagopesole (PZ) Italy; e-mail: gizzi@iisf.pz.cnr.i et al., 1995, 1997, 2000), it has been discovered that Melfi has a history of earthquakes with intensity from strong to annihilating in the MCS scale (Sieberg, 1932), among which the Irpinia event of July 23, 1930 (table I).

Regarding this last seismic event, all information contained in this catalogue has been taken principally from both the examination of the correspondence between central and local authority and from scientific bibliography. For some towns of the Apulia Region, the authors of the catalogue integrated the research by archive investigations of technical dossiers drawn up from the Office of Civil Engineers (Genio Civile). In order to evaluate the level of information detectable from these sources in other towns, the dossiers compiled by the Special Office of Civil Engineers of Melfi (afterwards USGCM, Ufficio Speciale del Genio Civile di Melfi) after 1930 Irpinia earthquake were systematically analysed. Eight towns in the Basilicata Region were under the jurisdic- 
Table I. List of the earthquakes felt in Melfi. The seismic events are extracted from Boschi et al. (2000). $I_{0}=$ epicentral intensity; $I_{s}=$ intensity in Melfi (scale MCS). In order to simplify, the intensity is shown in Arabic numerals.

\begin{tabular}{ccccccc}
\hline \hline Date & Time & Lat & Long & $I_{0}$ & $I_{s}$ & Epicentral zone \\
\hline 05/12/1456 & $03: 00$ & 41.300 & 14.717 & 11.0 & 8.5 & Italia Centro-Meridionale \\
08/09/1694 & $11: 40$ & 40.867 & 15.400 & 10.0 & 8.0 & Irpinia-Basilicata \\
20/03/1731 & $03: 00$ & 41.267 & 15.750 & 9.0 & 7.0 & Foggiano \\
$29 / 11 / 1732$ & $07: 40$ & 41.083 & 15.050 & 10.5 & 6.5 & Irpinia \\
20/02/1743 & $16: 30$ & 39.850 & 18.783 & 9.0 & 5.5 & Basso Ionio \\
26/07/1805 & $21: 00$ & 41.500 & 14.467 & 10.0 & 6.0 & Molise \\
01/02/1826 & $16: 00$ & 40.517 & 15.733 & 8.0 & 4.6 & Basilicata \\
14/08/1851 & $13: 20$ & 40.950 & 15.667 & 10.0 & 10.0 & Basilicata \\
14/08/1851 & $14: 40$ & 41.000 & 15.650 & 7.5 & 8.5 & Melfi \\
09/04/1853 & $12: 45$ & 40.817 & 15.217 & 9.0 & 4.6 & Irpinia \\
16/12/1857 & $21: 15$ & 40.350 & 15.850 & 11.0 & 7.0 & Basilicata \\
08/09/1905 & $01: 43$ & 38.667 & 16.067 & 10.0 & 3.0 & Calabria \\
07/06/1910 & $02: 04$ & 40.900 & 15.417 & 8.0 & 7.0 & Irpinia-Basilicata \\
13/01/1915 & $06: 52$ & 41.983 & 13.650 & 11.0 & 3.0 & Marsica \\
23/07/1930 & $00: 08$ & 41.050 & 15.367 & 10.0 & 9.0 & Irpinia \\
18/08/1948 & $21: 12$ & 41.583 & 15.750 & 7.5 & 3.5 & Puglia Settentrionale \\
21/08/1962 & $18: 19$ & 41.233 & 14.950 & 9.0 & 5.5 & Irpinia \\
23/11/1980 & $18: 34$ & 40.850 & 15.283 & 10.0 & 7.0 & Irpinia-Basilicata \\
07/05/1984 & $17: 50$ & 41.667 & 14.050 & 8.0 & 3.5 & Appennino Abruzzese \\
11/05/1984 & $10: 42$ & 41.717 & 14.083 & 7.0 & 3.5 & Appennino Abruzzese \\
\hline & & & & & & \\
\hline
\end{tabular}

tion of this office: Melfi, Atella, Barile, Rapolla, Rionero in Vulture, Monticchio, Ripacandida and Ginestra.

The historical approach to the evaluation of the effects of earthquakes in urban areas has already been applied to several important urban centres with different spatial resolution of damage pattern (Boschi et al., 1993; Esposito et al., 1995; Favali et al., 1995; Guidoboni and Ferrari 1995; Rovelli et al., 1995; Tertulliani and Riguzzi, 1995; Molin and Paciello, 1999; Faccioli and Pessina, 2000; Guidoboni et al., 2003).

The approach to the technical sources has also been applied to the analyses of several earthquakes. The used technical reports can only be relative to the damage to public and religious buildings (1832 Umbria and 1895 Firenze earthquakes, in Boschi et al., 2000) but also to the damage of the private ones inferred from the cumulative or the building-scale damage re- ports (Ferrari, 1986; Moroni et al., 1993; 1781 Romagna, 1818 Catania and 1929 Bologna earthquakes, in Boschi et al., 2000).

Our research focused on two aspects, the first regarding the institutional response to the disastrous event in the towns of the Vulture area; the second is mainly relative to the damage pattern in the historical town of Melfi.

As far as the first part is concerned, this research provided information both on the typology of interventions applied in short and medium-long term intervals and on the modalities used and the rapidity of their application. This was possible thanks to the analysis of 76 archive units or folders (buste) constituting the entire portion of the General Series (afterwards SG) concerning the earthquake of 1930 found in the Archivio di Stato in Potenza (ASPZ, Interventi eseguiti sul territorio, Fondo del Genio Civile, Serie Generale (1930-1940), Buste 1-76). 
As regards the second part, the main purpose of the study was to disclose the urban area of Melfi most affected by the disaster. In this way, the important step of research was drafting a detailed historical centre damage map. From this point of view this piece of research represents, for the 1930 Irpinia earthquake, the first test executed on a whole urban area and individual housing unit scale. The outcome of this research is the result of the analyses carried out on 101 archive units contained in the Specific Series (afterwards SS) (ASPZ, Perizie di danno alle abitazioni di Melfi, Fondo Genio Civile, Serie Specifica (1930-1941), Buste 40-140). These units include about 2400 dossiers or files, each of them contains information on the postseismic repairing procedures with building techniques description of the housing units and technical-economic-administrative data.

In detail, the aims of the second part of this research are the analysis of damage, economic aspects and temporal trend of buildings repair. As regards the relationship among damage distribution, building techniques, structural and territorial vulnerability, other studies and research activities are currently underway. In this essay, only preliminary considerations will be dealt with, so further studies and research activities will be necessary.

As is well known, to highlight phenomena of seismic amplification/attenuation or different building vulnerability, a crossed analysis of the factors that determine the seismic risk is a fundamental key-point. Therefore, variability of territorial and building vulnerability can be seen as a weak point of the anthropic-territorial system. Particular specific conditions of those weak points can change an earthquake into a disaster (Alexander, 1990).

The usefulness of an historical approach in damage assessment is also due to the ambiguous interpretation of the seismic response by the in situ analysis. For example, the site-effect inferred from the horizontal-to-vertical spectral ratio $H / V$ of microtremors, the well-known Nakamura's technique (Nakamura, 1989), is contradicted by various authors (Bonilla et al., 1996; Lachet et al., 1996; Seekins et al., 1996).

Summarising, we underline the importance, from a methodological point of view, of an in- depth analysis of historical damage which preferably will lead to the drawing up of a seismic scenarios catalogue of urban towns (see Guidoboni and Ferrari, 2000). In this way, a complementary relation with well-known traditional catalogues will be accomplished.

\section{Historical evolution and seismic history of Melfi}

The historical evolution of Melfi and its surrounding areas is tied to its seismic history. In particular, the continuous change of its urban design is not only the result of social-economic dynamics which usually characterize the history of every settlement, but is also the result of interventions carried out after the earthquakes that have affected Melfi since medieval times. From this point of view, the analysis of the urban-historical evolution of a town, as is well known, is very important (Guidoboni and Ferrari, 1995).

The first traces of human presence in the territory of Melfi date back to the 7th and 8th centuries B.C. Historical tradition shows that the foundation of the town dates back to the 8th century (Araneo, 1866). But only during the Norman Age (11th and 12th centuries) did Melfi become an important town, as confirmed by documentary and narrative sources.

At present, historical research shows an urban history made up of various expansion phases. The first phase, dating back to the 12th century, included an urban sector found in the south. It was characterized by a radial morphology whose cores were the castle and Piazza Umberto. The town walls surrounded the borders of this urban sector and went up through the slopes on the east side of the town and included the cathedral.

In the second phase (13th-14th centuries) the town walls expanded to include the southeastern zone. Many of the most important buildings were erected along the Rua Grande, now known as Corso Vittorio Emanuele.

Around the mid 15th century, the new outer walls were conformed to the defensive requirements linked to the development of gunpowder. Furthermore, most of the town was reconstructed after the devastating earthquake in 1456. Af- 


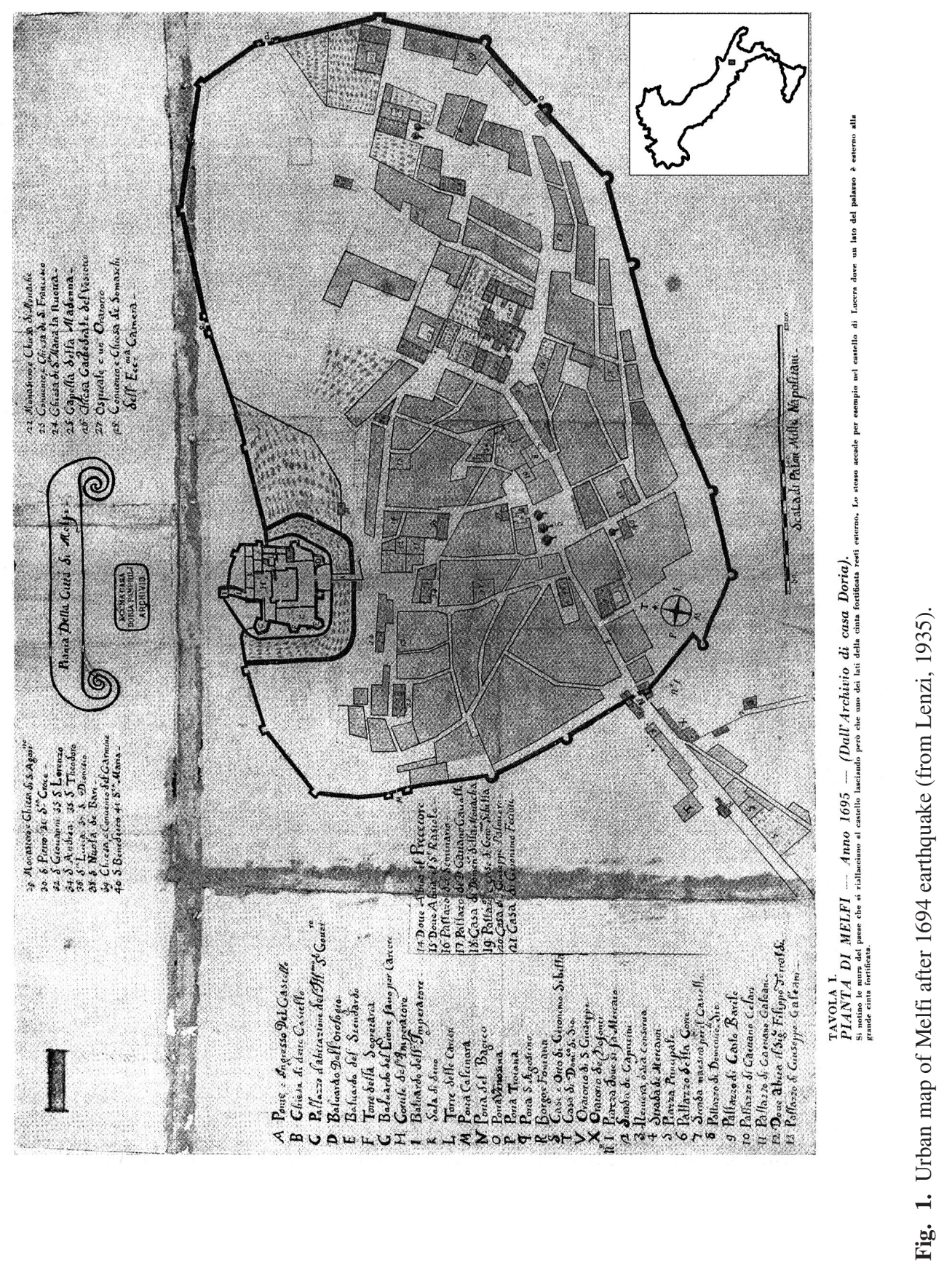


ter the 1528 Lautrec's sack, the eastern zone, now known as the Chiucchiari quarter, underwent new urban settlement which is characterised by an array of rectangular city blocks.

During the 17th century, outside the city walls and close to the southern entrance to the town, a village called San Michele developed, near the site now called the Bagni quarter. This last urbanhistorical phase was documented by a significant map going back to 1695 (Lenzi, 1935) (fig. 1). This map reveals the urban situation after the 1694 earthquake, which caused the collapse of fifty buildings. The most important buildings of the age were: the castle, of which a relevant part was brought to the ground by the earthquake and the cathedral, which suffered heavy damage. There were also over 21 churches and five monasteries, which were severely damaged.

During the next post-seismic decades there was a gradual development of the town in other free areas and, above all, in the extramoenia. An even more devastating earthquake hit the Vulture area in 1851. The zone most struck was the south-western part of the town close to the Bagni gate (Arabia, 1852).

In 1857 , there was the strongest earthquake in the 19th century, whose epicentre was localized in Val d'Agri (Boschi et al., 2000). It damaged even the chief town of the Basilicata Region, mainly the western area (Gizzi, 2000), but in Melfi the shake caused only cracks in numerous houses, but there were no collapses and, therefore, change in the urban framework.

On the contrary, further changes took place after the 1930 seismic event, which caused the shifting of a part of the Bagni quarter. Finally, during the second half of the 20th century, the town extended beyond the Melfia stream.

\section{The July 23, 1930 earthquake in the Vulture area}

After the disastrous seismic event of 1851, which directly affected Melfi, another strong earthquake ruined the area of Vulture. Indeed, the epicentre of the 1930 earthquake was localised close to this area. Valensise and Pantosti (2001) have detected the seismogenetic fault by historical, geological and geodynamic constraints. The estimated length of the fault is $32.6 \mathrm{~km}$ with a strike of $109 \pm 011$ degrees. The local stress field probably is connected to a tear fault (Galli et al., 2002).

The seismic event, whose epicentral intensity was $I_{o}=\mathrm{X}$ MCS and $M_{e}=6.7$ (Boschi et al., 2000), hit at 00:08 GMT an area extending about $6500 \mathrm{~km}^{2}$. It caused heavy damage to the territory ranging from Melfi to Ariano Irpino and killed 1404 people (fig. 2), causing severe

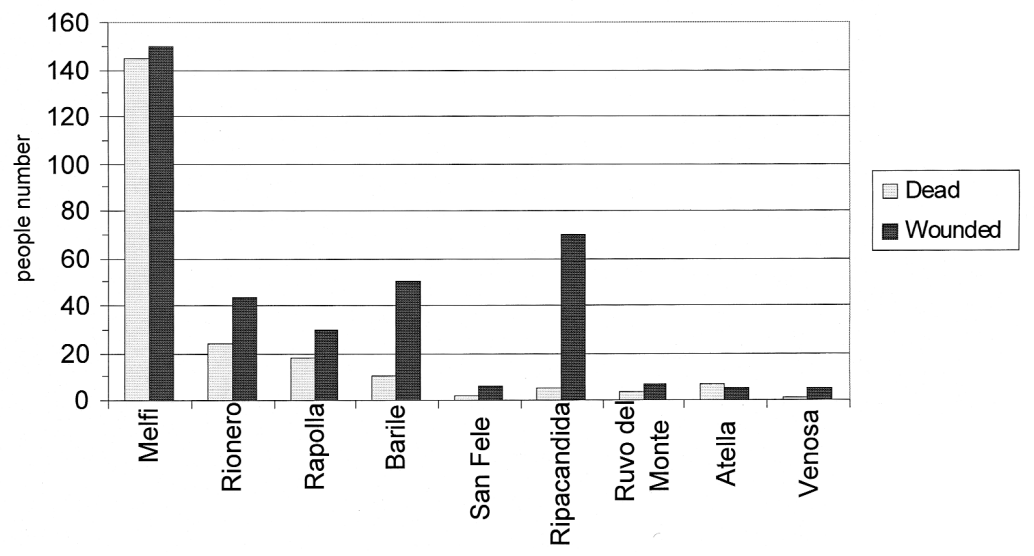

Fig. 2. People killed and wounded by the 1930 earthquake in the Vulture towns (ASPZ, Terremoto del 1930. Prospetto riepilogativo dei morti e feriti, Fondo Prefettura, Affari generali (1913-1932), Busta 771). 
damage to the urban framework (ASPZ, Terremoto del 1930. Prospetto riepilogativo dei morti e feriti, Fondo Prefettura, Affari generali (1913-1932), Busta 771). In particular, 29\% of the damaged buildings were localized in Melfi (figs. 3 and 4) (ASPZ, Relazione sull'opera ..., Fondo Prefettura, Affari generali (1913-1932), Busta 774). The epicentre zone was about 180 $\mathrm{km}^{2}$ wide and the general macroseismic field elongation went along the Apennine fault which triggered the event.
This earthquake, whose effect in Melfi was evaluated at IX degree on the MCS scale (Boschi et al., 2000), caused 145 deaths, that is about $1.2 \%$ of the population which, on the basis of the census given in 1921, was 12653 (ASPZ, Censimento della popolazione..., Fondo Prefettura, Affari generali (1913-1932), Busta 249). These data are not in accordance with Alfano (1931), but agree with Majo (1931).

The seismic event had devastating consequences on people's social organization, al-

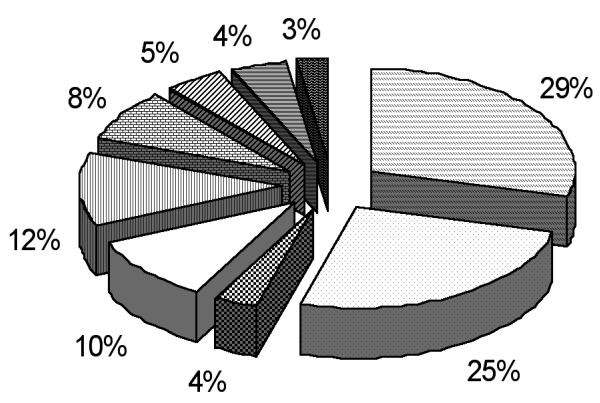

\begin{tabular}{|c|}
\hline 曰 Melfi (ternitory) \\
\hline$\square$ Rionero \\
\hline 冈 Atella \\
\hline$\square$ Barile \\
\hline 四 Ripacandida \\
\hline 㯖 Rapolla \\
\hline San Fele \\
\hline 目 Ruvo del Monte \\
\hline 图 Rapone \\
\hline
\end{tabular}

Fig. 3. Damaged buildings in the Vulture area (ASPZ, Relazione sull'opera ..., Fondo Prefettura, Affari generali (1913-1932), Busta 774).

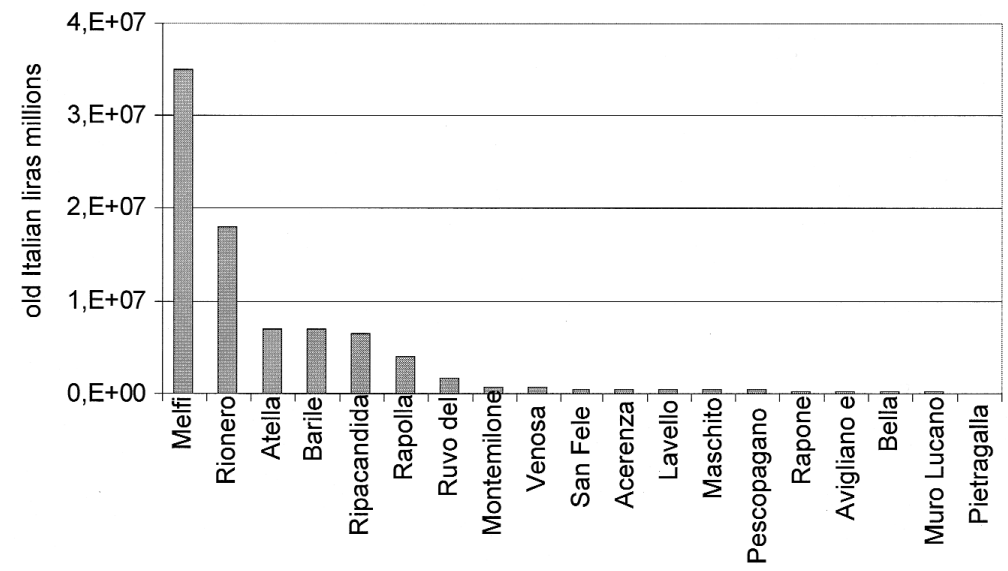

Fig. 4. Economic damage to the buildings in Vulture towns. Ten million old Italian lire are equal to about 8560000 million of Euro revalued to the present time (ASPZ, Relazione sull'opera ..., Fondo Prefettura, Affari generali (1913-1932), Busta 774). 


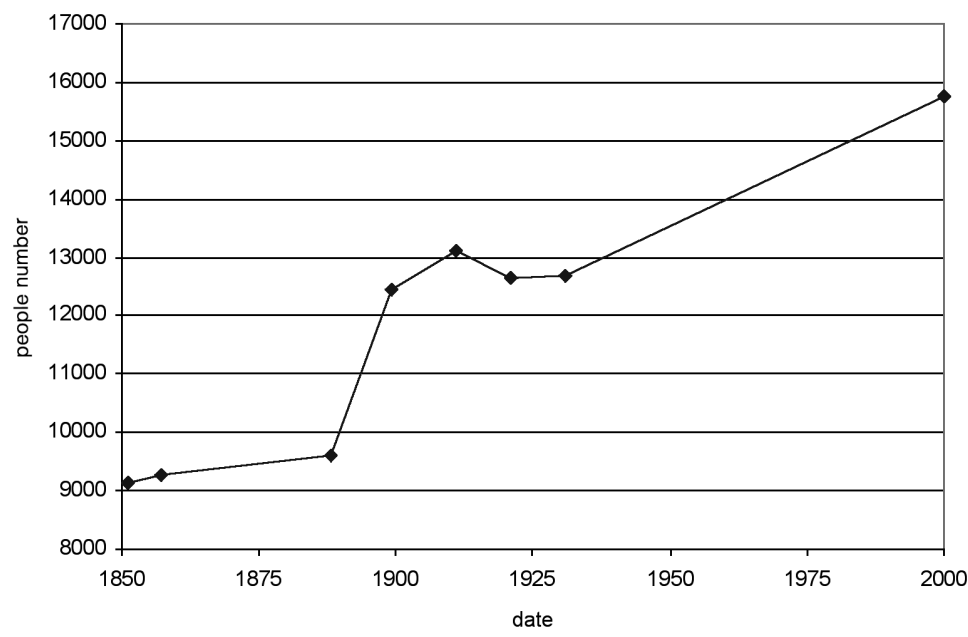

Fig. 5. Demographic trend in Melfi from the 19 th to the 21 st century (for references, see text).

ready seriously affected by World War One (1914-1918). These factors, combined with the medium-long term effects of the earthquake, caused the lowest level of demographic growth in the area in the last 150 years (ASPZ, Censimento della popolazione..., Fondo Prefettura (1913-1932), Busta 249; Bozza, 1890; Strafforello, 1899; Boschi et al., 2000) (fig. 5). Moreover, these combined consequences had a heavier outcome on the population than that of the disastrous local earthquake of 1851. Indeed, after it demographic growth had a rapid increase. Furthermore, the 1930 earthquake caused many environmental effects, such as landslide phenomena, liquefaction and soil fractures (Boschi et al., 2000; Michetti et al. 2000; Esposito et al., 2001). The phenomena which occurred in Melfi can be classified as changes in the landscape (Valensise and Guidoboni, 2000). In fact, «a very deep wellshaped crevasse with a five-metre diameter opened up in the lowest part of the town...» («nella parte bassa del paese si aprì un crepaccio di cinque metri di diametro, a forma di pozzo, molto profondo») (Cavasino, 1935), and furthermore, a wide landslide caused the partial shifting of an inhabited zone of the town.

\section{The 1930 earthquake in the Fondo of the Civil Engineers}

As said before, the principal source used to carry out this piece of research on the 1930 earthquake was the documentation provided by the Civil Engineers, divided into two parts.

The SG supplies information regarding the interventions carried out in the Vulture territory and contains a statistical summary of damage report of the area, general rules on damage assessment, geological surveys on the territory, procedure for sites partial shifting and, finally, documents relative to the construction of earthquake-proof buildings (casette asismiche). On the other hand, the SS part regards the damage to public and private buildings in some of the towns under the jurisdiction of the Civil Engineers. As a whole, the SG is made up of 76 fascicles, while the SS contains 285 . One hundred units of the latter series regard only the town of Melfi. For every damaged housing unit there is a corresponding dossier containing the identification data (owners, cadastral data), the descriptions of the materials and the building techniques used for reconstruction, the damage assessment, the summaries of the repairs or 
restorations of each unit and the administrative documents on the progress of those interventions. These data mainly originated from the damage assessment technical reports and tests of repairing works. Administrative data come also from the correspondence between the USGCM and the Ministry of Public Works.

\subsection{Data analysis: methodology}

Before reviewing the different typologies of acquired data, it is opportune to understand the methodological approach adopted for documentation analysis. This represents a fundamental point for a correct use of the data (Guidoboni, 2000). The study of earthquakes of the 20th century presents objective difficulties even if typologically different from the earthquakes of distant age. Indeed, in this case, the difficulties of interpretation related to social, political and economic contexts often set as a limit to identify the true effect of an earthquake. As for recent earthquakes, the limits are not re- lated to lack of information but to the difficulties in tracking down that piece of information. In some cases, this is due to the «scattering» of the data caused by numerous bureaucratic steps and also to the lack of an inventory of the public institutions archives.

In the case of the Fondo of the Civil Engineers dealing with the earthquake of 1930, the problem was the lack of an inventory which did not allow sequential and hierarchically structured research, typical of the analysis of archive sources. These difficulties mainly had to do with the analysis of the SG, because it is based on different topics. In order to overcome these difficulties, the study was done in two phases.

In the first phase an inventory of documents preserved in the SG was made, while, in the second an in-depth study on both series was carried out. In the first phase, the main problem was the temporal analysis of the overall procedure of documentation elaboration. In fact, the archive units and their relative files are neither in chronological nor in subject order. Therefore, the study proceeded first by making a typological invento-

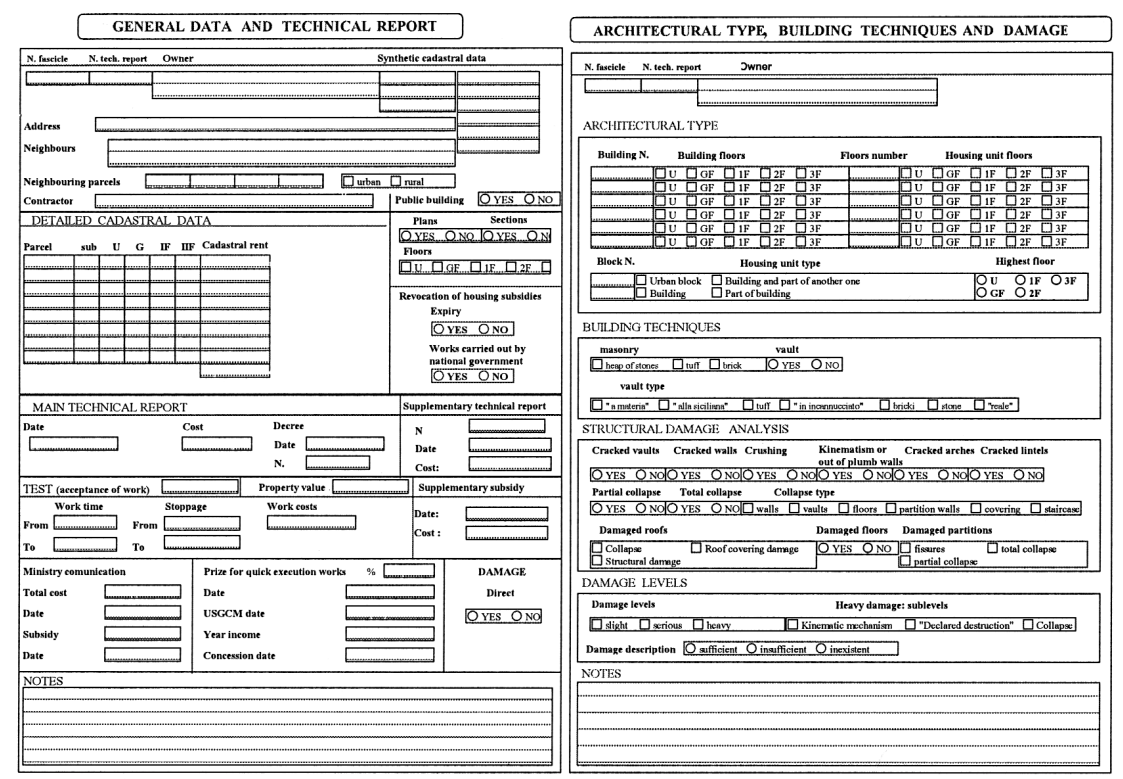

Fig. 6. Index cards used to record and analyse the archive data. 
ry of documents and organising it on a chronological basis. This allowed us to examine in detail the whole procedure of every administrative document. After this phase, the second one started with a true analysis of the documentation.

As far as the SS is concerned, a proper index card, made up of two sections, was planned. It was useful to enter and successively manage the gathered data collected from 2400 files and implemented in a relational database. The open structure of a digital archive allowed us to update and expand them by acquiring new data from future studies (fig. 6).

The first section of the index card contains the fields related to the identification and repairing cost estimates of the housing unit with its administrative steps, while the second section contains detailed information on the architectural and building features and structural damage suffered. The database was referenced according to a cadastral map, attached to the technical documentation, dating back to the beginning of the 20th century, to be able to easily locate all housing units on the urban territory of Melfi. This cartography is the nearest in time to the 1930 topography, and it guarantees nearly a one-to-one correspondence with the 1930 Melfi urban framework, avoiding the difficulties of damage buildings localisation due to lack of a map coeval with the seismic event. Indeed, in this case a crossed and multi-temporal analysis of toponymical and cadastral data is necessary (Esposito et al., 1995). However, the difficulties of localisation of buildings damaged by old earthquakes can also be overcome using a present-day plan of the city (Guidoboni et al., 2003), even though an uncertain localisation of damaged buildings is possible (Faccioli and Pessina, 2000).

However, in the present study, an integration of the cadastral map with a cartography extract attached to the archive source, has occasionally been carried out.

The main problem encountered during the study of the SS was to assign the correct and standardised semantic value to all the statements. This was carried out by a crossed analysis and a contextual examination of the files.

First of all, it is necessary to understand that the technical reports relative to damage assess- ment included in the dossiers belong to two different typologies: some of them are drawn up by the USGCM and others are compiled by engineers entrusted by the owner. Nevertheless, it was decided that the analysis should only have regarded the first typology of technical reports, to acquire typologically uniform information without involving subjective interests.

This approach was also applied to religious buildings because the reports of ecclesiastic authorities were always discordant with those of the Civil Engineers. On the contrary, Guidoboni et al. (2003) did not seem to find this difficult, probably due to the crossed analysis of different institutional sources.

However, a problem with these analysed reports was the right interpretation of the damage descriptions, because the adjective or adverbs used was not always clear. To overcome this difficulty, a comparative analysis on part of the documentation was carried out. In fact, $55 \%$ of the technical reports had a brief description of the damage suffered as well as an estimate, including indications on the work to carry out. The comparison between the two descriptions allowed us to understand the meaning of expressions such as «disconnected roof» («tetto sconnesso») or «upset roof» («tetto in disordine») and, consequently, to have a correct attribution of the damage, even for those dossiers where documentation was not complete.

The term «disconnected roof» normally indicated also a dislocation of roof beams, while «upset roof» usually meant only a disjointing of the tile roof. Another example is the meaning of the expression «wall with heavy cracks» («muro fortemente lesionato») which often indicates a crack across the wall or a detachment of it from another. From the point of view of damage assessment, the perception of the different semantic meaning of the expressions plays an important role. In summary, the analysis of technical terminology allowed the damage to be codified in synthetic-descriptive characteristics useful to fill out the index cards.

Another problem regards the effective damage analysis of the housing unit. In this case it is important to underline that during the initial post-seismic phases, improvements and/or extension works were usually included in technical 
Table II. Classes of damage with relative description used to classify the effects on the buildings.

\begin{tabular}{c|c|l}
\hline \hline Damage classes & Sub classes & \multicolumn{1}{c}{ Description } \\
\hline \multirow{3}{*}{ Heavy } & Collapse & $\begin{array}{l}\text { Total and partial collapse of one or more structural components } \\
\text { such as walls or roofs. }\end{array}$ \\
\cline { 2 - 3 } & Kinematic mechanism & $\begin{array}{l}\text { Macroscopic dislocations («strapiombo») of one or more struc- } \\
\text { tural components. }\end{array}$ \\
\cline { 2 - 3 } & Declared destroyed & $\begin{array}{l}\text { Particular case of post-seismic history of Melfi. This sublevel } \\
\text { refers to some housing units (about 11\% of the total) «declared } \\
\text { destroyed» which needed to be rebuilt in other areas because of } \\
\text { the geological instability of the site. For most of these (about } \\
\begin{array}{l}\text { 85\%) no damage description can be found while for the others } \\
\text { the heavy damage level was always inferred by technical reports. }\end{array}\end{array}$ \\
\hline \multirow{2}{*}{ Serious } & - & $\begin{array}{l}\text { Evidence of cracks across the walls with ejection of parts of ma- } \\
\text { sonry and important detachment between walls and roofs and be- } \\
\text { tween orthogonal walls. }\end{array}$ \\
\hline & - & $\begin{array}{l}\text { An evident separation between plaster and walls or capillary } \\
\text { cracks. }\end{array}$ \\
\hline
\end{tabular}

reports, since definite rules for damage assessment had not been indicated. The necessity to proceed in a more rigorous way was established by the rules issued by the USGCM. From a methodological point of view, the analysis of the damage level, which was indicated in the technical reports compiled before these orders, was therefore conducted much more cautiously.

Furthermore, many technical reports were carried out during the higher intensity period of the aftershocks; consequently the damage described could be connected to possible cumulative effects. In particular, about $20 \%$ of urban housing and $7 \%$ of rural housing were the object of damage assessment before 20 September 1930, the day of the last aftershock felt in Melfi. Nevertheless, in some cases, the reports explicitly refer to the damage caused by aftershocks and, in general, the increase in the effects on housing is not sufficient to justify a different attribution of damage classification. In case the effect of aftershocks had brought variations in classification, its description was sifted trying to gather the effective damage caused only by the main shock.

Regarding the modalities of cataloguing seismic effects on buildings, we referred to damage survey cards, planned by the Gruppo
Nazionale Difesa dai Terremoti (CNR-GNDT, 2000). These cards consider three damage levels such as: heavy, serious and slight. The attribution of damage is described in detail in table II.

As regards the slight damage a brief consideration is necessary. We do not have a technical report for all the buildings. This is linked either to the absence of damage or to the lack of the damage ascertainment application because of slight structural damage. However, the presence of numerous reports relative to slight damage suggest the former. Therefore, the scenario damage map here shown must be considered conservative as concerns minor damage. This analysis is in accordance with Guidoboni et al. (2003) which deals with the seismic scenario of Palermo. It is obvious that underestimation of minor damage depends on the typology of the sources inspected.

\section{Type of data acquired: institutional response in the Vulture area and damage in Melfi}

Based on the interpretative criteria given above, the study of documentation allowed us to draw up different typologies of information that 
can be summed up in two parts, according to the structuring and division of the archives source. While the first dealt with the actions carried out by the public administration in the towns involved in the Vulture area, the second analyses in detail the territorial distribution of the damage in the historical centre of Melfi and the time-dependent trend of the reconstruction phase.

\subsection{Institutional response in the Vulture area}

As a consequence of the earthquake of July 23rd 1930, the Italian government issued the Decree Law of August 3rd 1930 (R.D.L. 1065). According to this law, the interventions provided concerned the construction of earthquakeproof buildings, the authorisation to pay credit to private citizens and public entities in order to repair their housing units and, finally, the planning and the partial shifting of some geologically unstable urban areas. In the Vulture area the application of this law was entrusted to the USGCM (Boschi et al., 2000).

\subsubsection{Interventions carried out on the Vulture area}

The study on strong earthquakes in past times highlighted three possible typologies of intervention on damaged buildings: the reconstruction in situ, the abandonment and disappearance of the site and its shifting and reconstruction from scratch (Guidoboni and Ferrari, 2000).

Both the reconstruction in situ and the partial shifting were implemented for the communities of the Vulture area affected by the 1930 earthquake. The first aspect involved the construction of earthquake-proof buildings and indirect or direct repairing works of housing units by the government. Indeed, the USGCM built 224 earthquake-proof buildings in all with an expense of 12 million old Italian lire (about 10272000 Euro) (ASPZ, Relazione sull'attività ricostruttiva ..., Fondo Genio Civile, Serie Generale (1930-1940), Busta 3) (table III).

The Special Office selected the locations of the new buildings. This task was difficult because it was also necessary to consider future
Table III. Earthquake-proof buildings built by Civil Engineers in the Vulture area. Melfi urban districts are shown on the map of fig. 8 .

\begin{tabular}{ccc}
\hline Town & Urban district & Number \\
\hline Melfi & Rione Bianchi & 10 \\
& Rione Vittoria & 100 \\
& Contrada Foggiano & 5 \\
Rionero & Contrada Potasso & 2 \\
in Vulture & Posta di Atella & 3 \\
& Contrada Fornace & 35 \\
& $\begin{array}{c}\text { Contrada S. Antonio } \\
\text { Barile }\end{array}$ & 10 \\
& $\begin{array}{c}\text { Contrada Convento } \\
\text { and Contrada Ferrovia }\end{array}$ & 20 \\
Rapolla & $\begin{array}{c}\text { Rione Paradiso } \\
\text { Ripacandida }\end{array}$ & 18 \\
& $\begin{array}{c}\text { Peripheral part } \\
\text { of the town }\end{array}$ & 10 \\
Atella & $\begin{array}{c}\text { Peripheral part } \\
\text { of the town }\end{array}$ & 8 \\
Ginestra & $\begin{array}{c}\text { Peripheral part } \\
\text { of the town }\end{array}$ & 3 \\
&
\end{tabular}

plans of expansion of urban centres, especially the most populated ones, like Melfi and Rionero in Vulture. In towns like Atella, Ripacandida and Ginestra the new housing units did not form real districts.

In some cases, the choice of areas for the new housing units was difficult owing to the geomorphological and geotechnical features of the sites, the landslide phenomena and the presence of multiple and intercommunicating grottoes, as in Barile town. Because of these territorial features, a part of the Southern Melfi area which included the buildings «declared destroyed» («dichiarate distrutte»), was shifted to other zones. This aspect will be dealt with in the following sections.

\subsection{Earthquake-damage in Melfi}

In this second part of the study, we analyse the damage from a statistical point of view both for urban and rural buildings and the pattern damage in the historical centre of Melfi. Before reviewing these aspects it is opportune to examine the general background of the building features and the methodological criteria of damage analysis. 


\subsubsection{Building features}

Damage effects of an earthquake depend not only on the seismic hazard and the seismic response of the site, but also on building vulnerability. This is correlated to the quality of building materials and techniques, the architectural shape and restoration history.

To supply a preliminary view of building features, a sample of 600 files has been analysed containing a detailed description of as many other housing units relative to the SS.

The sample is significant because it gives a general tangible view of the most used construction typologies at the time of the 1930 earthquake. In particular the vertical structures are made up of load-bearing walls, built in three different way: lava rock ashlars, roughened, split or not yet formed in blocks $m_{1}$; tuff dressed stones, in regular and horizontal strings $m_{2}$; and masonry in brick $m_{3}$.

In order to provide further information on the application methods of the various typologies of construction, the data taken from the written sources were integrated by means of an in situ survey revealing that $m_{1}$ was the oldest and the most used constructive typology, made up of two versions. The first known as $m_{1 a}$, consists of mostly uncut lava rocks and, in smaller quantities, rough-hewed blocks placed in irregular strings. The second, known as $m_{1 b}$, is also made up of lava rocks, rough-hewed or split rocks placed in regular horizontal and sub horizontal strings. The building materials originated in large part from local underground volcanic areas such as the so-called «haüynofiro» of Melfi, which was particularly used because of its good mechanical properties (Radina, 1958; Masini, 1995). The stone materials for construction of the $m_{1}$ type walls were acquired from this source.

Another material highly used at the time was tuff since it is an outcrop in the southern area of the town and it is a ductile building material. A negative aspect is that it has less resistance. In many buildings having more than one floor, the $m_{1}$ masonry with lava blocks was used for lower levels whereas $m_{2}$ tuff masonry was used for higher storeys. The most used binding material was sand mortar with common lime. Mortar with common and pozzolan lime was less used.
Wall sections were generally composed of one piece in $m_{3}$ and in most of the $m_{2}$ typologies, while multiple pieces were used mostly in $m_{1}$ masonry, particularly in walls more than $60 \mathrm{~cm}$ thick. After the earthquake of 1930, many walls were reconstructed using the $m_{1 b}$ typology with brick strings, as indicated by the technical rules of the time (R.D.L. 682/1930).

As concerns the horizontal structures, three typologies are the most common: vaults, wooden-beam and small vaults with iron and perforated bricks. The vaults made up of lava ashlars using barrel or pavilion types of construction were mostly used on the ground floor, whereas the lighter vaults, consisting of bricks placed edgeways (the so-called «volte alla siciliana») or of perforated cylinder shape bricks, were used for the covers. Finally the use of false ceiling vaults (the so-called «incantucciato») was quite common.

On the whole, the level of the earthquakeproof technique in Melfi was good compared to the general situation of the rest of Basilicata. This was due to the experience of builders who had to reconstruct after every earthquake. In fact, according to Helly (1995), when earthquakes repeat themselves on average every two or three generations, it is more likely that there will be a culture handing down methods from one generation to another. This culture includes not only prevention but methods of post-seismic reconstruction as well.

Nevertheless, because of the economic conditions of populations, prevention activities were performed principally on the most important buildings, such as Melfi castle where tie-bars were placed after the 1694 Irpinia earthquake. This intervention represented a rare and new typology of earthquake proof improvement: «[...] in the whole Reign where damage occurred also owing to slight earthquakes...» («[...] la cosa che non stila in questa Città ne tampoco in tutto il regno dove poi succede de le rovine ad ogni poca scossa di teramotti...») (Lenzi, 1935). Furthermore, tie-bars had already been placed in the castle before the Irpinia earthquake and helped to prevent worse damage to the castle.

A more common post-quake intervention was the buttress (barbacane), which was applied above all after the 1851 earthquake. 
Table IV. Analytical procedure for $i_{u}$ and $p$ evaluation.

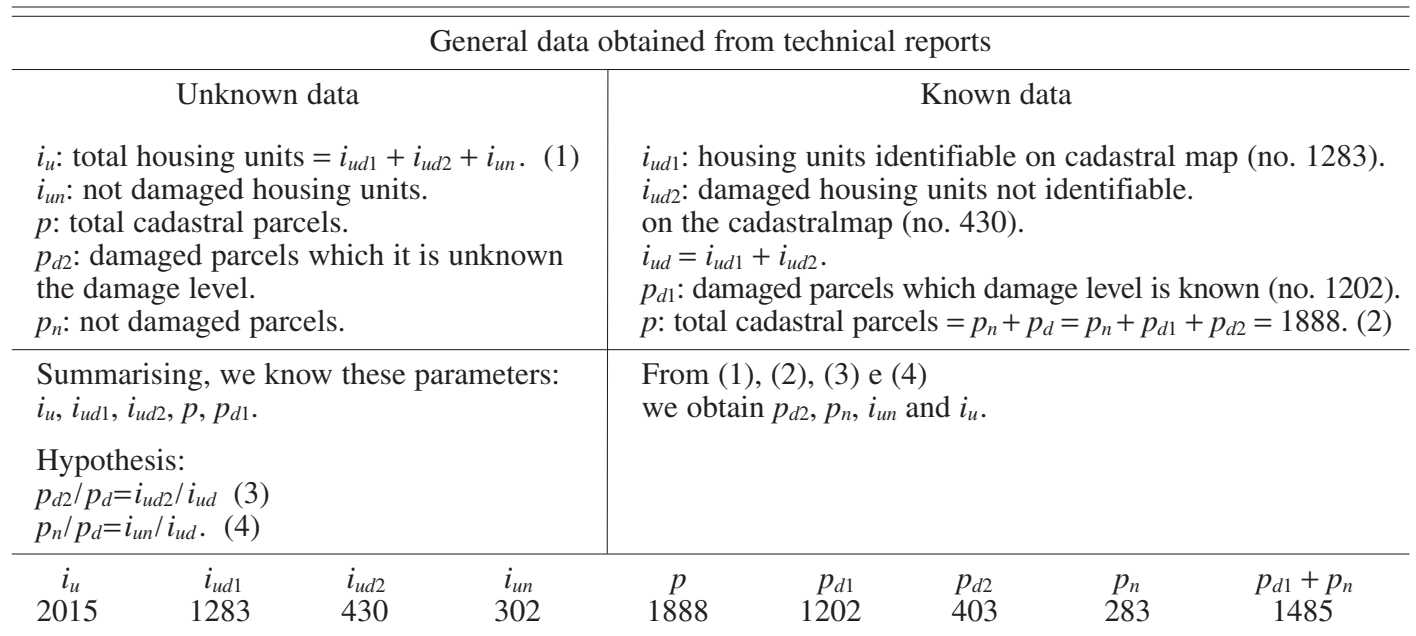

\subsubsection{Damage elementary unit: housing unit and cadastral parcels}

To obtain a parametric output relative to the damage level in Melfi, the data found in each dossier has been analysed. This approach will also be useful to evaluate the site macroseismic intensity.

Before quantifying these data, it is necessary to define the basic elementary unit used in statistical counting. As is known, earthquake damage usually refers to 'housing units' $(h)$ or 'houses'. But what do we mean when we say 'housing unit'? Generally, this term means the family unit, characterized by the use of exclusively one family and composed by one or more cadastral parcels $(p)$. In particular, as regards Melfi, each file corresponds to a housing unit. Starting from this point of view, we detected two damage assessment parameters or damage elementary units: the housing unit and the cadastral parcel. In this way, we analyzed some problems.

First, a bijection between $h$ and $p$ does not exist. Moreover, by using $h$ as an elementary unit, another problem arises: the total number of urban housing units $h_{u}$ existing in Melfi in 1930 is unknown or uncertain. In fact, we know the number of damaged housing units $h_{u d}$, but we do not know the number of the undamaged housing units $h_{u n}$; furthermore, only part of $h_{u d}$ is locatable on the cadastral map $h_{u d 1}$.

Vice versa, if we use parcels as elementary units, their total number $p$ is known, but it is not possible to know the damage level of all the parcels. This fact depends on the lack of cadastral certificates in such dossiers. Therefore, an analytic procedure was adopted to identify these unknown parameters which allow us to assign the damage level by using both $h_{u}$ and $p$ (see table IV). With this approach, for example, the inferred $h_{u}$ was confirmed by another source (Alfano, 1931), which indirectly indicates about 2000 housing units in the urban center of Melfi.

\subsubsection{Statistical analysis of damage}

On the basis of the elementary units $(h, p)$, a statistical analysis on the territorial level of damage classified as heavy, serious and light was carried out (table V). Similar values relative to heavy damage level and fluctuating between $23.1 \%$ and $23.3 \%$ were found thanks to the two elaborations. Such data are comparable to the data supplied by the coeval sources, from which we inferred values of $21 \%$ (Alfano, 1931) and 
Table V. Damage level of the buildings in Melfi. Left colons are relative to the damage level for the urban housing units $\left(i_{u}\right)$ and urban cadastral parcels $(p)$. Central columns indicate the damage level relative to the rural housing units. Right columns show the damage relative to the three classes of heavy damage: collapse, kinematic mechanism and declared destroyed.

\begin{tabular}{lcccc|cc|ccc}
\hline \hline $\begin{array}{l}\text { Damage } \\
\text { classes }\end{array}$ & $\begin{array}{c}\text { Urban } \\
\text { no. } i_{u}\end{array}$ & $\begin{array}{c}\text { Urban } \\
\text { no. } p\end{array}$ & $\%$ & $\begin{array}{c}\text { Rural } \\
\text { no. }\end{array}$ & $\begin{array}{c}\text { Relative } \\
\%\end{array}$ & $\begin{array}{c}\text { Heavy damage } \\
\text { classes }\end{array}$ & $\begin{array}{c}\text { Urban } \\
\text { no. } i_{u}\end{array}$ & $\%$ \\
\hline Heavy & 469 & 23.3 & 437 & 23.1 & 90 & 21.3 & Collapse & 169 & 36.0 \\
Serious & 708 & 35.1 & 766 & 40.6 & 190 & 44.9 & Kinematism & 115 & 24.5 \\
Slight & 536 & 26.6 & 341 & 18.1 & 143 & 33.8 & Declared destroyed & 185 & 39.5 \\
Not damaged & 302 & 15.0 & 344 & 18.2 & - & - & - & - \\
\hline Total & 2015 & 100.0 & 1888 & 100.0 & 423 & 100.0 & - & 469 & 100.0 \\
\hline
\end{tabular}

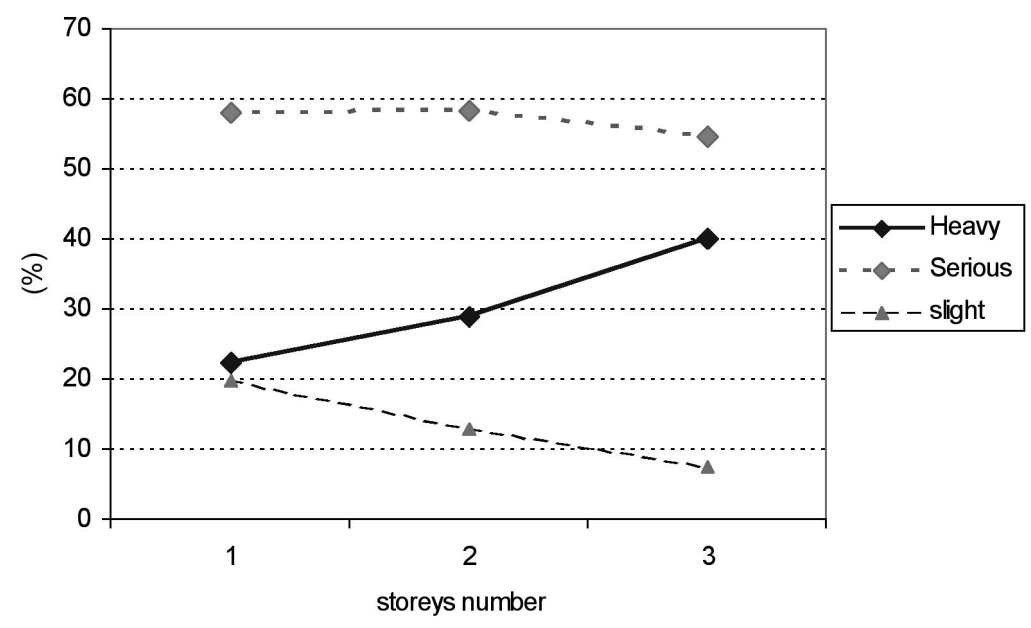

Fig. 7. Damage in relationship to the storeys number. The analysis carried out on a sample of 806 urban cadastral parcels shows that the damage level is a rising function of the storeys number.

$22 \%$ (Majo, 1931) of the so-called «collapsed houses» which also include the buildings declared destroyed (dichiarate distrutte). We underline that these coeval publications cannot supply us with the real damage level, but only an appraisal of it. In fact, on the basis of the overall analyses of the dossiers, we found that the last technical report was compiled in 1941.

A variation of data is registered for the other damage levels, such as serious damage. This is tied to the choice specificity of the elementary damage unit. Particularly, in the case of a parcel relative to more housing units, the dam- age assignment is determined by the heaviest damage suffered. In any case, if we sum the two classes - 'serious' and 'slight' - they reach values included in a restricted range, between $58.7 \%$ and $61.7 \%$.

The damage analysis regarded rural buildings as well, but for these the total number of housing units $\left(h_{2}\right)$ is not available. Therefore, the percentages refer only to the damaged housing (table V).

From the above-mentioned data, a value of IX on the MCS has been attributed to site macroseismic intensity. This is in accordance 
with Boschi et al. (2000). Furthermore, a damage evaluation in accordance with the European Macroseismic Scale (Grünthal, 1998) has been carried out. The description of the scale and the warnings about the use of the macroseismic scale for the seismic scenario of the past reduced the interpretative difficulties relative to this type of analysis. In particular, considering that most of the houses fell into the vulnerability classification ' $\mathrm{B}$ ' that is, in "simple stone» buildings, and that «many buildings of vulnerability class $B »$ suffered damage of grade 4 , an intensity degree equal to IX EMS was assigned.

The available data also allow us to analyze the damage depending on architectural features and building techniques. Such analyses, currently under study, already disclose two preliminary aspects. The first is the position of individual buildings in urban blocks. In particular, the buildings located at the head or on the corner of blocks underwent the most damage. The second aspect is the influence of height or of buildings storeys number. In fact, the analysis carried out on a sample of 806 urban cadastral parcels shows that the damage level is a rising function of the storeys number (fig. 7).

\subsubsection{Urban scenario of damage}

According to what is reported by the Giornale di Basilicata on July 26-27th 1930 and Civil Engineers (ASPZ, Relazione sull'attività ricostruttiva .... Fondo Genio Civile, Serie Generale (1930-1940), Busta 3) the earthquake caused the highest effects in an area generically identified in the southern part of the town. This caused the partial shifting of the districts into two new areas: one named Cappuccini sited in the area surrounding the railway station and another called Chiucchiari sited in the east part of the town (fig. 8).

From a detailed analysis of damage scenario as this research has shown, the main effects are concentrated along three areas: the southern one, coinciding with Bagno, Calcinaia, San Martino and Cappuccini zones; the centraleastern area, including Via Vittorio Emanuele, and the perimetrical sector of the whole hill where the town rises (fig. 9).
The highest damage level in these areas represent a constant factor also for other earthquakes, as is documented both for the local earthquake of Melfi in 1851 and for the most recent one in Irpinia in 1980. Indeed, the site analyses on 1851 earthquake differential damage caused in several urban centres of the Vulture area pointed out heavier damage to buildings situated on slopes (Palmieri and Scacchi, 1852). The event probably was caused by seismic amplification phenomena and earthquakeinduced landslides. These secondary effects were especially evidenced in the town of Melfi, where «pieces of house foundations rolled down from the midday side of the hill along with tuff landslide» («pezzi di fabbriche che appartenevano a' fondamenti delle case rotolati giù insieme con il tufo franato») (Palmieri and Scacchi, 1852). Another heavily affected area was that between Sant'Agostino church and Bagno town gate (Paci, 1853). Also with 1980 seismic event, the most affected area of Melfi was the south-central one, including the zones of Bagni and Calcinaia (Gazzetta del Mezzogiorno, 30/11/1980). In addition, the shake also brought about a wide landslide in the zone of Ferrara (Gazzetta del Mezzogiorno, 07/01/1981).

Starting from this historical background, preliminary geological surveys and building features were analysed. They seem to suggest that the damage pattern depends not only on structuralengineering factors, but also on the site seismic response. These considerations also come from the fact that very heavy damage does not seem to 'prefer' only the poorest areas of the town, where $80 \%$ of the affected population resided, but also its eastern side, traditionally inhabited by populations belonging to medium-high social classes. Here the population lived prevalently in buildings characterized by good conditions of stability and maintenance, even if made up of more levels and for this reason more vulnerable.

Moreover, in the southern part of the town, pyroclastic deposits originated from the volcanic activity of Vulture (La Volpe and Principe, 1994) outcrop. They are not very and not evenly cemented and therefore they can cause seismic amplification phenomena. This aspect was indirectly underlined in a scientific publication dating back to the time of the event: $« \ldots$ 


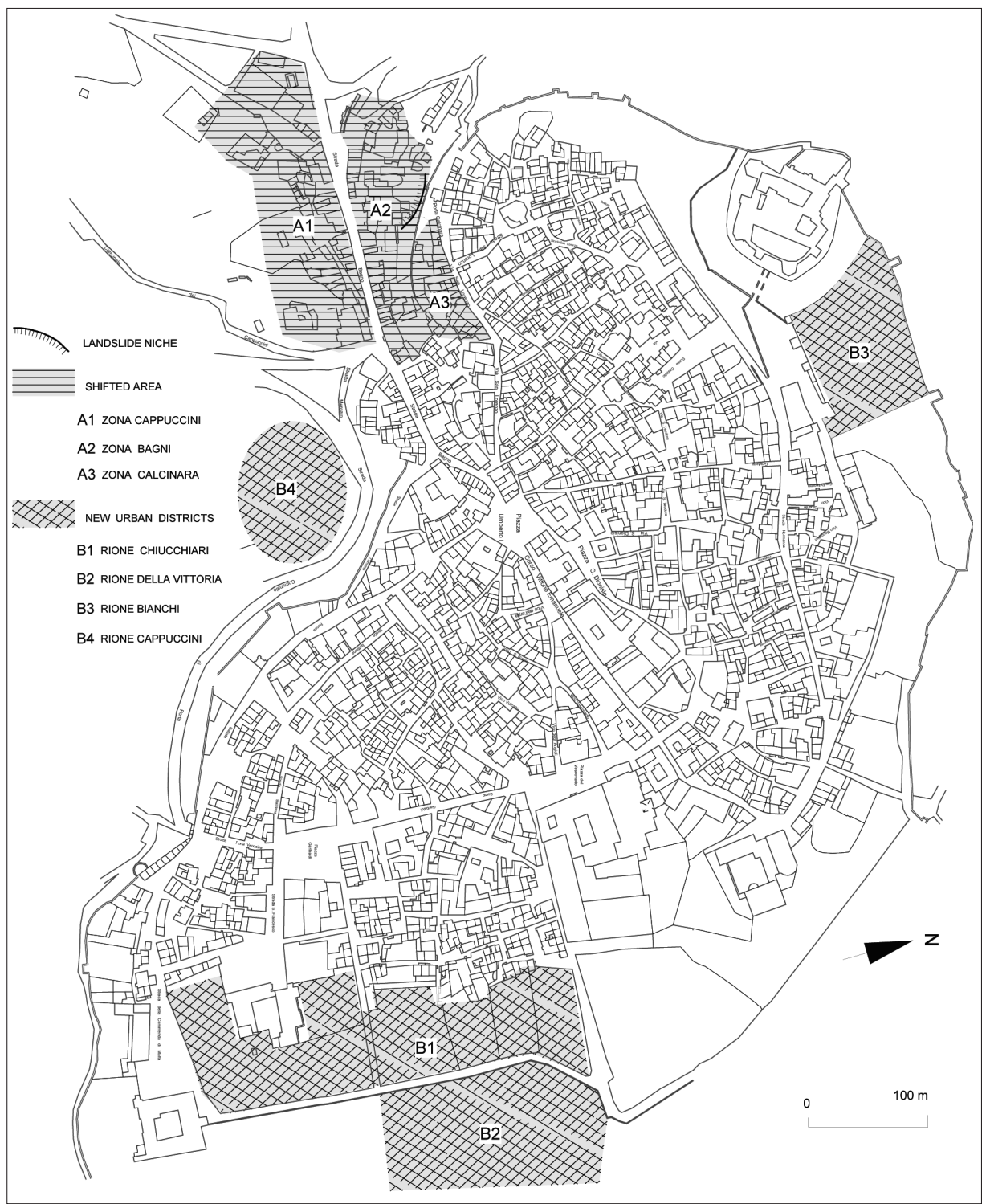

Fig. 8. Melfi urban map showing the new urban districts and shifted areas.

Melfi was seriously damaged at the hill foot, in an area known as Contrada Capanna, where incoherent deposits outcrop; while Contrada Castello suffered slight damage, since it was built on very hard rock» («... la città di Melfi fu assai danneggiata nella parte bassa in Contrada Capanna, fabbricata su terreno incoerente, mentre minori danni soffrì la Contrada Castello costruita sulla solida lava del Vulture») (Vari, 1931). 


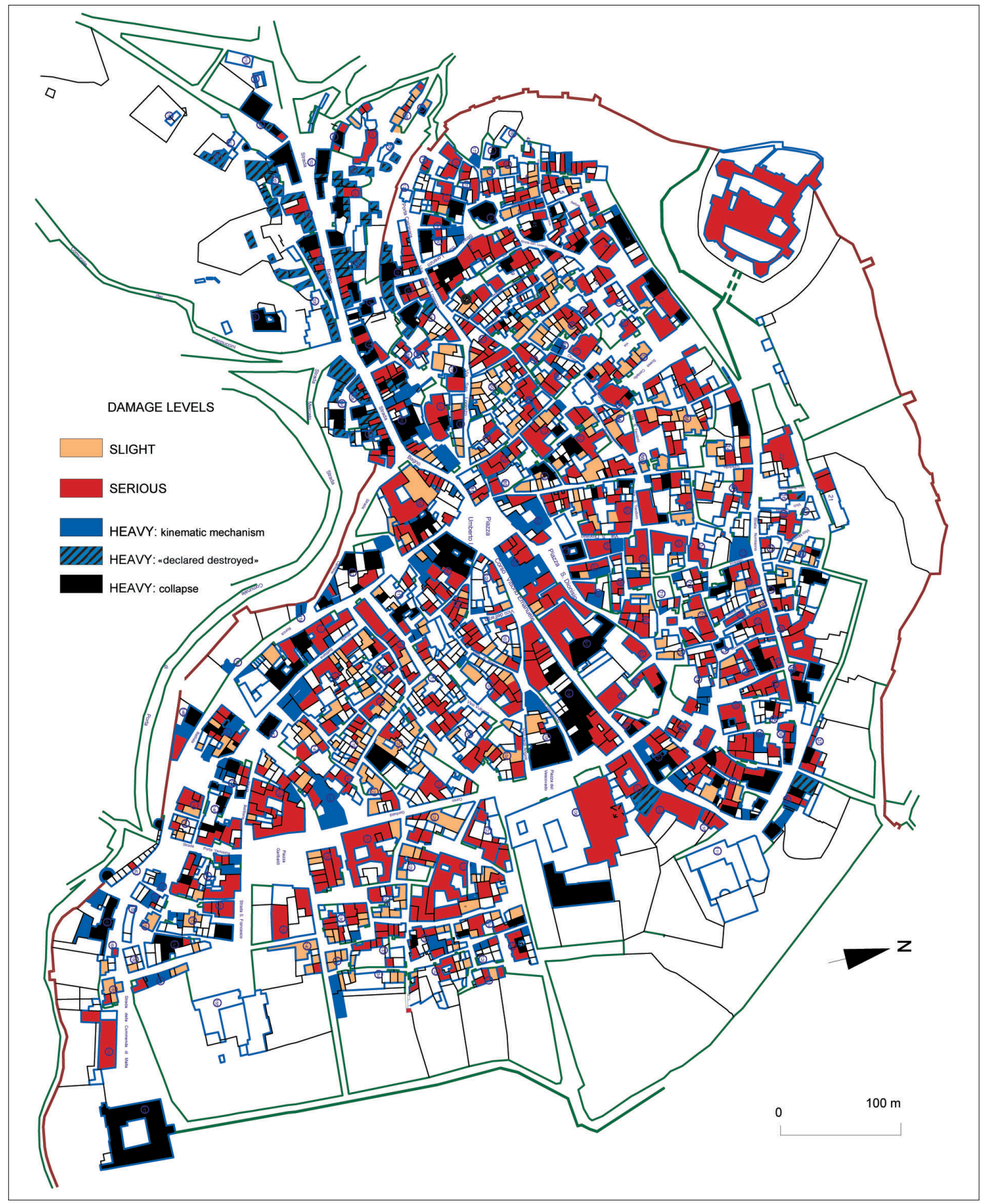

Fig. 9. Damage scenario of Melfi historical centre. The figure shows which the main felts were concentrated along three areas: the southern area, the central-eastern one and the perimetrical sector of the whole hill where the town rises. 
Furthermore, the highest level of damage in the southern area is also tied to the co-seismic landslide which occurred in Porta Calcinaia area and the collapse of some caves, as it was for San Martino zone. In detail, the niche of the landslide was observed in correspondence to the town walls, running along almost $80 \mathrm{~m}$. The earthquake-induced landslide phenomenon began eight days after the earthquake and was preceded by precursor such as the opening of tensile cracks.

As far as the central-eastern part of the town is concerned, it is important to note that on the top of the hill, detrital deposit is overlapped on the «haüynofiro» hard-rock. Although the upper unit is frequently hidden by urban framework, the presence of numerous grottoes, especially in the eastern part of the town, allows us a view of the covering. Thanks to geological surveys, we have inferred that the detritum thickness is very variable and in some areas it is at least six meters. The crossed analysis of these geological data and the damage pattern suggests that seismic amplification phenomena were probably caused by overburden detritus.

Lastly, the widespread heavy damage localised at the hill border is probably linked both to topographic amplification phenomena and to instability of rocky blocks, characterised by typical columnar joints. The latter, already in an unstable condition, tend gradually to widen because of slope decompression and appel au vide phenomena linked with the Melfia torrent erosion. In this context, the indirect seismic effect can cause rock falls or relative movement of rocky blocks along the fractures, as during the earthquakes in 1851 and 1930, with consequent indirect damage of overlooking buildings.

\subsubsection{Post-seismic reconstruction: modalities, times and costs}

With respect to the private reconstruction carried out by housing subsidies, the R.D.L. 1065/30 established two main bureaucratic steps. The first was presentation of the subsidy application followed by damage assessment by the USGCM.
Owners had 15 months to apply the intervention in case of strengthening or 24 months in case of demolition and reconstruction. Furthermore they could obtain other funds, known as a «bonus for quick execution works» («premio di acceleramento»).

Generally, during the damage assessment step, the USGCM initially favoured the building of housing units suffering minor damage, to re-establish the community quickly. The housing units suffering collapse or destruction were estimated only at the end, because they were to be relocated in different areas and required longer periods of planning and construction.

In order to evaluate the temporal trend of reconstruction in the town of Melfi, the technical reports included in all the dossiers have been analyzed. We refer to the reports relative both to damage assessment or planned works and to the tests of repair works. Furthermore, the costs estimated in the damage report were compared with and the funds actually paid out, such as reported by tests.

Regarding the first aspect, fig. 10 shows two phases of the post-seismic reconstruction: first lasted about nine months when about $90 \%$ of plans were carried out, the second one ended in September 1936. The passage between the two phases indicates the beginning of the testing phase. In particular, about three years after the earthquake, in July 1933, about 70\% of works carried out by private citizens with government contributions were tested, while $95 \%$ of them were tested only after six years, in June 1936.

These data indicate a rather rapid execution of the damage assessment phase and a slower trend of the tests phase. This can be linked to the numerous extensions granted by the USGCM on behalf of private citizens, especially in the cases of off-site reconstruction, which had to be carried out after urbanization works.

Observing fig. 11, which shows the cumulative percentage of works planned and tested in cost segments, the presence of two variation thresholds can be noted in the trend: 10000 and 20000 old Italian lire (£) that revalued (ISTAT, 2003) are equal to about 8560 and 17120 Euro. About $70 \%$ of planned works have a cost be- 


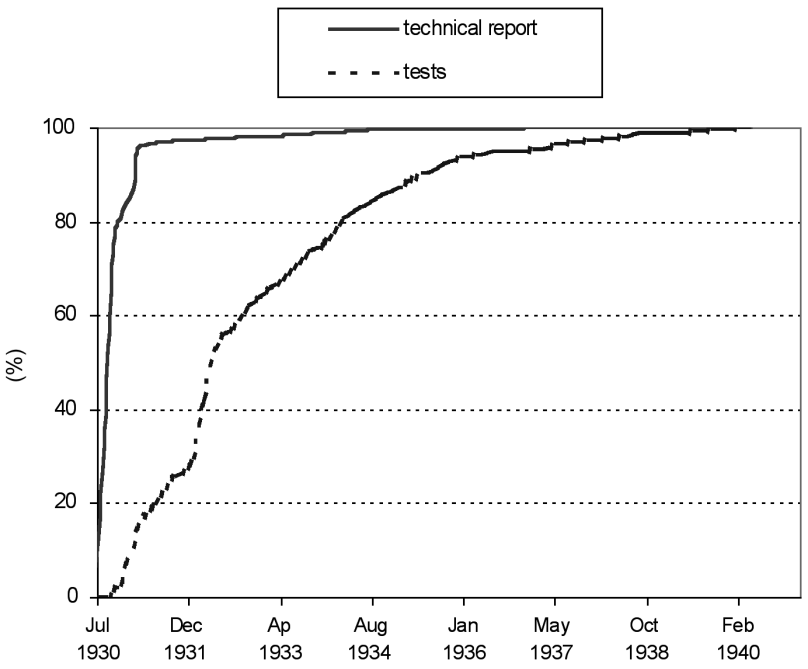

Fig. 10. Time-dependent analysis of the technical reports and tests.

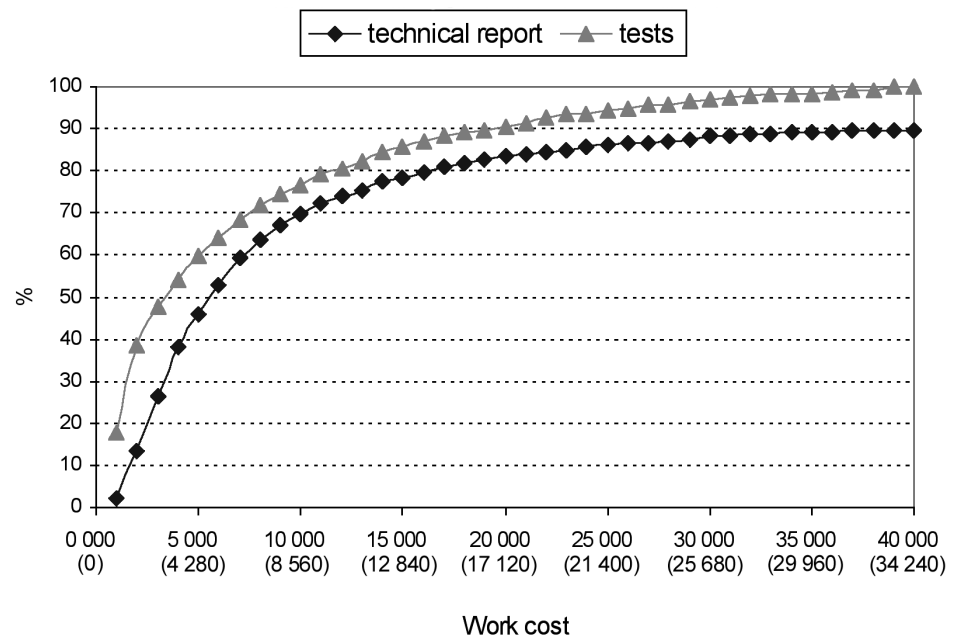

Fig. 11. The figure shows the cumulative percentage of works planned and tested in cost segments: the presence of two variation thresholds can be noted in the trend. The original works cost, relative to old Italian lire, have been revalued in Euro (in brackets), according to a coefficient proposed by ISTAT (2003).

low the first threshold. Another class cost, whose value is included between the first and the second threshold concerns about $13 \%$ of plans. A much lower percentage falls under the class of costs above the $£ 20000$ mark. Similar considerations regard the curve of tested works costs. It is staggered with respect to values ranging between $10 \%$ and $25 \%$. This is more 


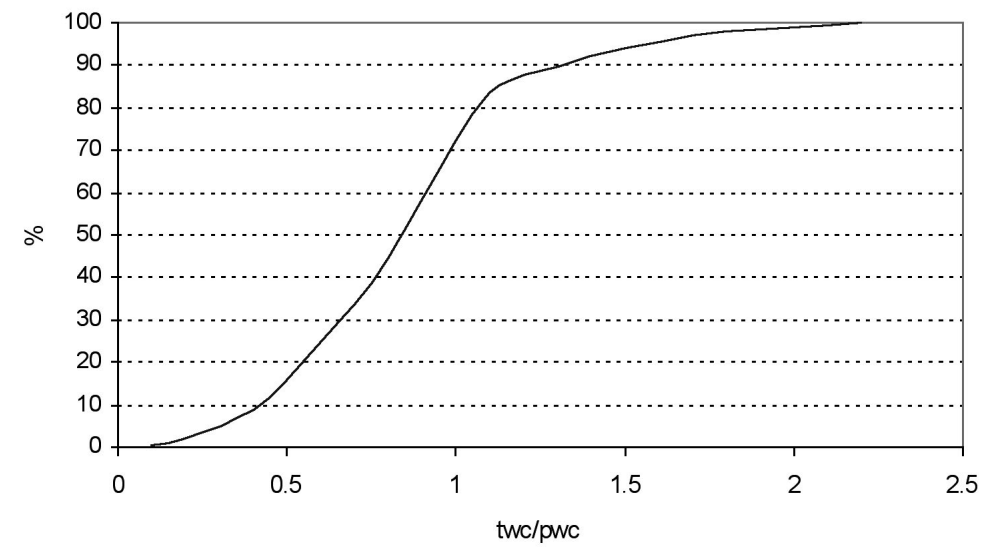

Fig. 12. Cumulative percentage of the ratio between tested works cost $(t w c)$ and planned works cost $(p w c)$ is observed. In $70 \%$ of cases, costs are reduced during the tests phase.

evident in fig. 12, where the cumulative percentage of the ratio between tested works costs $(t w c)$ and planned works costs $(p w c)$ is observed. In $70 \%$ of cases, costs are reduced during the testing phase. This can be linked to execution swiftness and a superficial survey of damage to a more careful check of restoration works in the testing stage and to scant public funds. Moreover, the first aspect can also explain the costs increase in the tests phase.

Funding regarded not only private housing, but public buildings as well. Frequently, the technical reports checked from the USGCM differed from those given by proprietary agencies. A significant example is the case of the castle, whose total cost of repair was about 564000 Euro (old $£$ 659160 ), but only $75 \%$ was financed by the government. The interventions were necessarily carried out because of the great deal of damage including the collapse of the main walls, the separation of the western facade, the heavy damage in the tower, church and emperor's tower. The most consistent damage was generally found on the second level and on the roof. On the other hand, the cost of the repair works to the cathedral was lower as the damage involved the vaults and the dome, which had suffered minor cracks.

Besides by financing for reconstruction, the USGCM repaired the housing units where it needed no more than 856 Euro (old $£ 1000$ ), in order to rapidly resettle the community in their houses. In the nine communities under the jurisdiction of the USGCM, 1754 housing units were repaired spending on average 913 Euro (old $£$ 1066.65) for each unit (ASPZ, Relazione sull'attività ricostruttiva ..., Fondo Genio Civile, Serie Generale (1930-1940), Busta 3).

From this, it can be deduced that the reconstruction in loco was carried out according to short-term and medium-term plans. On the contrary, relocation projects only followed medium-long term plans, involving the communities of Melfi and Rionero in Vulture.

As regards post-seismic building techniques, a typical action was the demolition of vaults and the building of girder and follow block floors. Plate floors and hollow tile floors were less used. Moreover, in order to link floors and walls, tie bars were more used than edge beams. As regards wall reinforcements, the tuff dressed stones and the lava rock masonry were reinforced using the same materials and adding regular brick strings. Demolished walls were rebuilt by brick masonry.

\section{Conclusions}

A detailed study on the Irpinia earthquake which occurred on July 23rd 1930 has been car- 
ried out with reference to the north-eastern area of Basilicata. Mainly, this research regarded both the general aspect of the 'bureaucratic response' of institutions in the towns of the Vulture and the local damage suffered by the town of Melfi. This was possible thanks to an analysis of the archive sources, currently preserved by the Archivio di Stato di Potenza. This documentation was provided by the Office of Civil Engineers, a special institution formed directly after the earthquake. Altogether, 176 fascicles were analysed: 76 for the bureaucratic response and 101 for the damage pattern in Melfi.

The research on the institutional response supplied a detailed view of all post-seismic interventions. It has been ascertained that the damage caused by the earthquake together with the bureaucratic decisions indirectly changed a part of urban planning especially in denselypopulated towns. This alteration was mainly due to population redistribution in the new districts. They can be classified into two types: one part built immediately after the seismic event consisted of earthquake-proof buildings; another part was planned and constructed in the medium-long term according to more articulated territorial planning. During the following years these districts represented areas of population attraction even for other ethnic groups. From a social and town-planning point of view the consequences can be interpreted as a necessary response to these phenomena.

The territorial analysis of Melfi damage allowed the evaluation of the site macroseismic intensity in IX degree, both in EMS and MCS scale.

Furthermore, the urban damage pattern and the temporal trend of reconstruction have been analysed. As regards the first aspect, the study disclosed that the areas with most damage are those in the southern, central-eastern and marginally peripheral sectors of the town. The crossed analysis of damage data and preliminary geological surveys seems to highlight seismic amplification phenomena tied to the area lithology and the morphology. Other causes of differential damage are the earthquake-triggered landslides and the instability of foundation soil, which was caused by relative movements along the joints of rock blocks, especially in corre- spondence of the hill border. Numerous collapse phenomena of grotto vaults indirectly caused damage to housing units.

With regard to the second aspect, we analysed the reconstruction time table. The data indicate that $50 \%$ of the reconstruction interventions was concluded in less than two years, while all the reconstruction and repairing works were concluded by 1940 .

Summarising, the historical damage pattern approach represents both a valid back-analysis approach to seismic microzoning and a good method to verify the in situ experimental analysis. Moreover, the housing units, like strongmotion sensors, also «register» the vulnerability of the building-soil system.

\section{Acknowledgements}

The authors are grateful to Dr. Graziano Ferrari for fruitful discussion. We extend our gratitude to Dr. Vincenzo Lapenna and Dr. Giovanni Martinelli for valuable advice.

Special thanks also to the staff of the Archivio di Stato di Potenza.

\section{REFERENCES}

Unpublished administrative and technical sources

ASPZ (Archivio di Stato di Potenza): Censimento della popolazione della Basilicata (1921), Fondo Prefettura, Affari generali (1913-1932), Busta 249.

ASPZ (ARChivio di Stato DI PotenZA): Terremoto del 1930. Prospetto riepilogativo dei morti e feriti. Fondo Prefettura, Affari generali (1913-1932), Opere Pie, Busta 771 .

ASPZ (ARCHIVIO DI STATO DI POTENZA): Relazione sull'opera di pronto soccorso a favore della popolazione di questa provincia colpita dal terremoto (9 Agosto 1930), Fondo Prefettura, Affari generali (1913-1932), Busta 774.

ASPZ (ARCHIVIO DI STATO DI POTENZA): Interventi eseguiti sul territorio, Fondo Genio Civile, Terremoto del 23 Luglio 1930, Parte 1. Serie Generale (1930-1940), Buste 1-76.

ASPZ (AArchivio di Stato di PotenZa): Perizie di danno alle abitazioni di Melfi, Fondo Genio Civile, Terremoto del 23 Luglio 1930, Parte 2. Serie Specifica (19301941), Buste 40-140.

ASPZ (ARChIVIO Di Stato di PotenZA): Relazione sull'attività ricostruttiva svolta nei comuni della Provincia di Potenza in conseguenza del terremoto del 23-7-1930 (7 
dicembre 1933), Fondo Genio Civile. Terremoto del 23 Luglio 1930. Parte 1. Serie Generale (1930-1940). Busta 3.

Daily newspapers

Gazzetta del Mezzogiorno, 07 Gennaio 1981 Gazzetta del Mezzogiorno, 30 Novembre 1980 Giornale di Basilicata, 26-27 Luglio 1930.

Scientific sources

AleXANDER, D. (1990): Calamità naturali. Lineamenti di geologia e studio dei disastri, Bologna.

AlfaNo, G.B. (1931): Il terremoto irpino del 23 Luglio 1930, Pubblicazione dell'Osservatorio di Pompei, pp. 57.

ARABIA, F.S. (1852): Relazione storica del tremuoto di Basilicata nell'anno 1851 (letta nella tornata del 14 dicembre dell'Accademia Pontaniana), Napoli.

Araneo, G. (1866): Notizie storiche della città di Melfi, Firenze.

Bonilla, L.F., J.H. SteIDL and A.G. Tumarkin (1996): Site amplification in the San Fernando Valley from weak and strong-motion data, in Proceedings of the 11th World Conference on Earthquake Engineering, June 23-28, Acapulco, Mexico.

Boschi, E., E. GUIDOBONI and D. MARIOTTI (1993): I terremoti dell'area siracusana e i loro effetti in Ortigia, in Sicurezza e conservazione dei centri storici. Il caso di Ortigia, edited by A. Giuffré (Laterza, Bari-Roma), 15-36.

Boschi, E., G. Ferrari, E. Gasperini, E. Guidoboni, G. SMRIGLIO and G. VALENSISE (1995): Catalogo dei Forti Terremoti Italiani dal 461 a. C. al 1980 (ING, RomaSGA, Bologna), pp. 973 with CD-ROM.

Boschi, E., E. Guidoboni, G. Ferrari, G. Valensise and P. GASPERINI (1997): Catalogo dei forti terremoti in Italia dal 461 a.C. al 1990 (ING, Roma-SGA, Bologna), vol. 2, pp. 644 with CD-ROM.

Boschi, E., E. Guidoboni, G. Ferrari, D. Mariotti, G. VAlensise and P. Gasperini (Editors) (2000): Catalogue of Strong Italian Earthquakes from 461 B.C. to 1997, Ann. Geofis., 43 (4). pp. 268 with CD-ROM.

BozzA, A (1890): La Lucania. Rionero in Vulture.

Cavasino, A. (1935): I terremoti d'Italia nel trentacinquennio 1899-1933, Annali del Regio Ufficio Centrale di Meteorologia e Geodinamica, vol. IV, s. III, $1-266$.

CNR-GNDT (2000): Scheda di $1^{\circ}$ Livello di Rilevamento Danno.

Esposito, E., L. LAURELli and S. PORFIDO (1995): Damage pattern in historical centers: Isernia, an example in Southern Italy, in Earthquakes in the Past: Multidisciplinary Approaches, edited by E. BosCHI, R. FUNICIELLo, E. Guidoboni and A. Rovelli, Ann. Geofis., XXXVIII (5/6), 663-677.

Esposito, E., R. Pece, S. Porfido and G. Tranfaglia (2001): Hydrological anomalies connected to earthquakes in Southern Apennines (Italy), Nat. Hazards Earth Syst. Sci., 1, 137-144.
Faccioli, E. and V. Pessina (Editors) (2000): The Catania Project: Earthquake Damage Scenarios for a High Risk Area in the Mediterranean (CRN-GNDT, Roma).

Favali P., F. Frugoni, D. Monna, L. Rainone, P. SignaniNI and G. SMIRIGLIO (1995): The 1930 earthquake and the town of Senigallia (Central Italy): an approach to seismic risk evaluation, in Earthquakes in the Past: Multidisciplinary Approaches, edited by E. BosCHI, R. Funiciello, E. Guidoboni and A. Rovelli, Ann. Geofis., XXXVIII (5/6), 679-689.

FERRARI, G. (1986): The Adriatic coast seismic period of May to August, 1916: some implication on the seismic zoning of the Rimini area, in Engineering Geology Problems in Seismic Areas, Bari, vol. 4, 407-420.

Galli, P., D. Molin, F. Galadini and B. Giaccio (2002): Aspetti sismotettonici del terremoto Irpino del 1930, in Il terremoto del «Vulture» 23 Luglio 1930 VIII dell'Era Fascista, edited by S. CASTENETTO and M. SEBASTIANO, Monografia del Servizio Sismico Nazionale (Istituto Poligrafico e Zecca dello Stato, Roma), 215-260.

GizZI, F.T. (2000): La valutazione della pericolosità sismica come strumento per la conservazione delle facies artistico-architettoniche dei centri storici: l'esempio di Potenza, Boll. Geofis., 23 (1/2), 51-70.

GRÜNTHAL, G. (Editor) (1998): European Macroseismic Scale 1998 (on line: http://www.gfz-potsdam.de/pb1/ pg2/ems_new/INDEX.HTM).

GuidOBONI, E. (2000): Method of investigation, typology and taxonomy of the basic data: navigating between seismic effects and historical context, Ann. Geofis., 43 (4), 621-666.

Guidoboni, E. and G. Ferrari (1995): Historical cities and earthquakes: Florence during the last nine centuries and evaluations of seismic hazard, in Earthquakes in the Past: Multidisciplinary Approaches, edited by E. Boschi, R. Funiciello, E. GUIDOBONI and A. Rovelli, Ann. Geofis., XXXVIII (5/6), 617-647.

Guidoboni, E. and G. FerRARI (2000): The effects of earthquakes in historical cities: the peculiarity of the Italian case, in Catalogue of Strong Italian Earthquake from 461 B.C. to 1997, edited by E. Boschi, E. GuIdobONI, G.Ferrari, D. Mariotti, G. VAlensise and P. GASPERINI, Ann. Geofis., 43 (4), 667-686.

Guidoboni E., D. Mariotti, M.S. Giammarinaro and A. RovelLI (2003): Identification of amplified damage zones in Palermo, Sicily (Italy), during the earthquakes of the last three centuries, Bull. Seismol. Soc. Am., 93 (4), 1649-1669.

HeLly, B. (1995): Local seismic cultures: a European research program for the protection of traditional housing stock, in Earthquakes in the Past: Multidisciplinary Approaches, edited by E. BoschI, R. Funiciello, E. Guidoboni and A. Rovelli, Ann. Geofis., XXXVIII (5/6), 791-794.

ISTAT (2003): Coefficienti per Tradurre Valori Monetari (on line: www.istat.it/dati/Rivalutazi/val-lira2001.htm).

LA Volpe, L. and C. Principe (1994): Il Monte Vulture. Guida all'escursione generale precongressuale, in Atti della 77a Riunione Estiva della Società di Geologica Italiana, Bari.

Lachet, C., D. HatzFeld, P.Y. Bard, N. Theodulidis, C. PAPAIOANNOU and A. SAVVAIDIS (1996): Site effects and microzonation in the city of Thessaloniki (Greece) - 
Comparison of different approaches, Bull. Seismol. Soc. Am., 86 (6), 1692-1703.

LenZI, G. (1935): Il Castello di Melfi e la sua Costruzione, Amatrice.

MAJo, E. (1931): Il terremoto irpino del 23 luglio1930, Boll. Soc. Nat., 43.

Masini, N. (1995): Materiali lapidei nell'edilizia storica in Basilicata, in Atti del Convegno «Il Recupero degli edifici antichi. Manualistica e nuove tecnologie», Napoli, 29-30 Ottobre 1993, vol. 1, 247-253.

Michetti, A.M., A.M. Blumetti, E. Esposito, L. Ferreli, L. Guerrieri, S. Porfido, L. SERVA and E. VitTORI (2000): Earthquake ground effects and seismic hazard assessment in Italy: examples from the Matese and Irpina areas, Southern Apennines, in Active Fault Research for the New Millennium. Proceedings of the Hokudan Symposium and School on Active Faulting, 279-284.

Molin, D. and A. Paciello (1999): Seismic hazard Assessment in Florence city (Italy), J. Earthquake Eng., 3, 475-494.

Moroni, A., D. Bellettati, E. Chignola and M. Stucchi (1993): The earthquakes of 1834 in the Northern Apennines, in Irpinia Dieci Anni Dopo, edited by E. BosCHI, D. Pantosti, D. Slejko, M. Stucchi and G. Valensise, Ann. Geofis., XXXVI (1), 301-308.

NAKAMURA, Y. (1989): A method for dynamic characteristics estimation of subsurface using microtremor on the round surface, Q. Rep. Railw. Tech. Res. Inst., 30, 25-33.

PACI, G.M. (1853): Relazione dei tremuoti di Basilicata del 1851, pp. 56.

PAlmieri, L. and A. SCACChI (1852): Della regione vulcanica del Monte Vulture e del tremuoto ivi avvenuto nel 14 agosto 1851, Napoli.
RadinA, B. (1958): Caratteristiche tecniche dello Hauynofiro di Melfi (Potenza), Riv. It. Geot., 3 (58).

Rovelui A., D Molin, L. Malagnini and A. Caserta (1995): Variability of damage pattern in Rome: combination of sources and local effects, in Fifth International Conference on Seismic Zonation, Nizza, vol. 2, 1359-1366.

Seekins, L.C., L. Wennerberg, L. Margheriti and H. P. LIU (1996): Site amplification at five locations in San Francisco, California: a comparison of $S$-waves, codas, and Microtremors, Bull. Seismol. Soc. Am., 86, 627-635.

SieberG, A. (1932): Geologie der Erdbeben, Handbuch der Geophysik, Gebr. Bornträger, Berlin, vol. 2, pt. 4, pp. 550-555.

Strafforello, G. (1899): La Patria. Geografia dell'Italia. Bari, Foggia, Lecce e Potenza, Torino.

Tertulliani, A. and F. Riguzzi (1995): Earthquakes in Rome during the past one hundred years, in Earthquakes in the Past: Multidisciplinary Approaches, edited by E. Boschi, R. Funiciello, E. GUIDOBoni and A. Rovelli, Ann. Geofis., XXXVIII (5/6), 581-590.

VALENSISE, G. and E. GUIDOBONI (2000): Earthquake effects on the environment: from historical description to thematic cartography, Ann. Geofis., 43 (4), 747-763.

Valensise, G. and D. Pantosti (2001): Database of Potential sources for Earthquakes larger than $M$ 5.5. in Italy, Ann. Geofis., 44 (suppl. to n. 1), pp. 180 with CD-ROM.

VARI, V. (1931): Il terremoto dell'Alta Irpinia (23 Luglio 1930), Boll. Soc. Sismol. It., 29, 181-196.

(received March 8, 2004; accepted June 28, 2004) 